\title{
Development of E-Business towards Labor Market for Higher Education
}

\author{
M. Ahsanul Mubdik ${ }^{a, 1, *}$, Delliana Eka W ${ }^{a, 2}$, Fachrul Kurniawan ${ }^{a, 2}$ \\ ${ }^{a}$ Universitas Islam Negeri Maulana Malik Ibrahim, Malang, Indonesia \\ ${ }^{1}$ ahsanuin09@ gmail.com; ${ }^{2}$ delypooh91@yahoo.com; ${ }^{3}$ fachrulk@ti.uin-malang.ac.id
}

\begin{tabular}{|c|c|}
\hline Article Info & ABSTRACT \\
\hline $\begin{array}{l}\text { Article history: } \\
\text { Received: September 3, } 2018 \\
\text { Revised: September 14, } 2018 \\
\text { Accepted: October 1, } 2018\end{array}$ & $\begin{array}{l}\text { The internet in business is used for information exchange, product catalogs, } \\
\text { promotional media, e-mails, bulletin boards, electronic questionnaires, and mailing } \\
\text { lists. The internet can also be used to dialogue, discuss, and consult with consumers on- } \\
\text { line, so that consumers can be involved proactively and interactively in the design, } \\
\text { development, marketing, and sale of products. By using the internet, we can run an } \\
\text { electronic business or commonly called e-business as a means of expanding } \\
\text { employment opportunities. Given the smaller quota to find employment, that e- } \\
\text { business is the right solution for college graduates. }\end{array}$ \\
\hline
\end{tabular}

Labor market

Higher education graduate

\section{INTRODUCTION}

Labor market opportunities in Indonesia are now increasingly narrow [1]. Many graduates from famous universities cannot work in elite companies due to increasingly fierce competition and not a few graduate students who still do not have permanent jobs [2]. The registration data for East Java civil service in 2012, totaled 17,014 people, whereas the quota needed was only 148 . This means that a percentage of the number of graduates who do not have permanent employment can only be taken and this is expected to increase in subsequent years. The number of companies in Indonesia is already much, but the growth in the human population is not accompanied by growth in existing jobs [3]. In many cases in Indonesia, many person seek to profit when registering prospective workers to an instance or industry. Some of them offer assistance to be accepted to work in an instance or industry with the condition of paying bribes.

\section{METHOD}

The study using qualitative methods to understand about what is experienced by research subjects such as behavior, perception, motivation, action, and so on [4], [5]. Holistically and with the description of words, and language in a particular natural context and by utilizing various natural methods.

The technique in the qualitative method used is by distributing questionnaires. This questionnaire contains a list of questions for respondents to look an answers from case study. In the questionnaire there are questions and answers that must be answered by the respondent. The respondents consists of 30 students majoring in Information Engineering UIN Maulana Malik Ibrahim Malang at 5th and 7th semester.

There are several advantages when using questionnaire technique such as [6]: (1) Questionnaires are good for large and scattered data sources. (2) Respondents do not feel disturbed, because they can fill out the questionnaire by choosing their own free time. (3) Questionnaires are relatively more efficient for large data sources. (4) Because the questionnaire does not include the identity of the respondent, the results can be more objective.

There are two types of questionnaire formats, namely Free Format and Fixed Format [7]. Free format questionnaire contains questions that must be filled out by respondents in the places that have been provided. While fixed format questionnaire has several forms of questions such as (1) Check-off Questions that are made so that the respondent can check-off the appropriate answers. (2) Yes/No questions that allow respondents to answer "Yes" or "No". (3) Opinion/choice questions that allow respondents to give their opinions.

\section{RESULT AND DISCUSSION}

Table 1 shows the results of the questionnaire used to find answers from this study. The results shows that some data 
which states that many IT students in semester 5 and semester 7 have experience in the field of E-Business, from data with a sample of 30 students, 19 people said they had done EBusiness activities.

Some cases state that many graduates from higher education do not have jobs for one reason is the limited number of employee quotas both government employees, teachers, and also company employees. From the data available of IT students in semester 5 and semester 7 it was found that more than $50 \%$ wanted to work as entrepreneurs. In expanding its entrepreneurship from survey data it was found that more than $50 \%$ of all answered "Yes" to doing EBusiness.

TABLE I. QUESTIONNAIRE RESULT

\begin{tabular}{|c|c|c|c|}
\hline No & Question Lists & Result & Total \\
\hline \multirow{4}{*}{1} & \multirow{4}{*}{ occupations of interest } & Learners & 12 \\
\hline & & Government employee & 7 \\
\hline & & Entrepreneur & 23 \\
\hline & & Company employee & 9 \\
\hline \multirow{3}{*}{2} & \multirow{3}{*}{$\begin{array}{l}\text { Work options when quota is full } \\
\text { (teachers, lecturers, government } \\
\text { employees) }\end{array}$} & Online works & 2 \\
\hline & & Entrepreneur & 23 \\
\hline & & Abstention & 5 \\
\hline 3 & Interest to do e-business & Yes & 30 \\
\hline \multirow{2}{*}{4} & \multirow{2}{*}{ have done e-business } & Yes & 19 \\
\hline & & No & 11 \\
\hline \multirow{8}{*}{5} & \multirow{8}{*}{ e-business has ever done } & Web designer & 6 \\
\hline & & $\begin{array}{l}\text { Software } \\
\text { programming }\end{array}$ & 8 \\
\hline & & Advertising & 10 \\
\hline & & Investment & 7 \\
\hline & & Trading & 7 \\
\hline & & Exchanger & 0 \\
\hline & & Other & 11 \\
\hline & & Abstention & 3 \\
\hline \multirow{10}{*}{6} & \multirow{10}{*}{$\begin{array}{l}\text { Form of E-Business that you want } \\
\text { to create }\end{array}$} & $\begin{array}{l}\text { Software } \\
\text { programming }\end{array}$ & 1 \\
\hline & & Design services & 3 \\
\hline & & $\begin{array}{l}\text { Electronic stuff } \\
\text { transaction }\end{array}$ & 1 \\
\hline & & Freelance analyses & 1 \\
\hline & & Developer & 1 \\
\hline & & Advertising & 1 \\
\hline & & Online transaction & 3 \\
\hline & & Trading & 1 \\
\hline & & Animation & 2 \\
\hline & & Event organizer & 1 \\
\hline \multirow{4}{*}{7} & \multirow{4}{*}{ Duration to do e-business } & $1-2$ years & 19 \\
\hline & & $2-3$ years & 2 \\
\hline & & $3-4$ years & 1 \\
\hline & & abstention & 8 \\
\hline \multirow{5}{*}{8} & \multirow{5}{*}{ Known sites } & Frelancer.com & 15 \\
\hline & & Guru.com & 2 \\
\hline & & Google.com/adsense & 21 \\
\hline & & Agea.com, exness.com & 7 \\
\hline & & Abstention & 7 \\
\hline \multirow{6}{*}{9} & \multirow{6}{*}{ Monthly income (IDR) } & $<100$ thousand & 1 \\
\hline & & 100 thousand-1 & 4 \\
\hline & & million & \\
\hline & & $>1$ million & 3 \\
\hline & & Not sure & 2 \\
\hline & & abstention & 20 \\
\hline
\end{tabular}

\section{CONCLUSION}

The most desirable job by IT students of UIN Maulana Malik Ibrahim Malang is Entrepreneurship as many as 23 people. Besides the entrepreneurship, the second most desirable job is 12 teaching staff. The average student already knows what e-business is, what e-business has ever done, and even 19 out of 30 of our correspondents have ever done ebusiness or online business.

Based on the results of the questionnaire, it can be concluded that the average IT student of UIN Maulana Malik Ibrahim Malang is already familiar with online business and some of them are already do it. So it can be concluded that the development of e-business or online business at IT UIN Maulana Malik Ibrahim Malang has been run, as well as stock trading, investment, software programming, and advertising. There are even informatics engineering students who have their own monthly income. There are 3 of our correspondents who already have an income more than 1 million every month.

\section{References}

[1] K. Kis-Katos and R. Sparrow, "Poverty, labor markets and trade liberalization in Indonesia," J. Dev. Econ., vol. 117, pp. 94-106, 2015.

[2] E. R. Allen, "Analysis of Trends and Challenges in the Indonesian Labor Market," Asian Dev. Bank, 2016.

[3] J. W. Lee and D. Wie, "Technological change, skill demand, and wage inequality: Evidence from Indonesia," World Dev., vol. 67, pp. 238-250, 2015.

[4] V. Pathak, B. Jena, and S. Kalra, "Qualitative research," Perspect. Clin. Res., vol. 4, no. 3, 2013.

[5] V. A. Lambert and C. E. Lambert, "Qualitative Descriptive Research: an Acceptable Design," Pacific Rim Int. J. Nurs. Res., vol. 16, no. 4, pp. 255-256, 2012

[6] K. B. Wright, "Researching Internet-based populations: Advantages and disadvantages of online survey research, online questionnaire authoring software packages, and web survey services," J. Comput. Commun., vol. 10, no. 3, 2005.

[7] E. Codó, L. Dans, and M. M. Wei, "Interviews and questionnaires," Blackwell Guid. to Res. methods Biling. Multiling., pp. 158-176, 2008. 